\title{
THE EUROSDR GEOBIM PROJECT - DEVELOPING CASE STUDIES FOR THE USE OF GEOBIM IN PRACTICE
}

\author{
C. Ellul ${ }^{1, *}$, F. Noardo ${ }^{2}$, L. Harrie ${ }^{3}$, J. Stoter ${ }^{2}$ \\ ${ }^{1}$ Department of Civil, Environmental and Geomatic Engineering, University College London, London, UK - c.ellul@ucl.ac.uk \\ ${ }^{2} 3$ D Geoinformation group, Delft University of Technology, Delft, The Netherlands - (f.noardo, j.e.stoter)@tudelft.nl \\ ${ }^{3}$ Department of Physical Geography, Lund University, Lund, Sweden - lars.harrie@ nateko.lu.se
}

\section{ICWG}

KEY WORDS: GeoBIM, Industry Foundation Classes, CityGML, interoperability, BIM, 3D city models

\begin{abstract}
:
Although the use of location-based data (location coupled with semantic information) within Geographical Information Systems (GIS) and from Earth Observation (e.g. satellite) sources has been long established for decision makers, this has only recently been reflected in the construction sector with a more recent move from Computer Aided Design (CAD) to Building Information Modelling. BIM has opened up an additional source of valuable location-based data, with particular focus on the architecture, structural and engineering detail of both buildings and infrastructure projects. As with most if not all location data, while BIM can be used on its own, major benefits are to be derived from integration with other data sources. When this is done with GIS, the result is known as GeoBIM and although there are some similarities between the two, challenges to integration are both technical and non technical, in particular the need for clear case studies to motivate both developers and senior management. There are synergies to be gained from a multi-national, coordinated approach when addressing these challenges, where participants can benefit from each-others' experience and where the needs of users and the National Mapping and Cadastral Agency (NMCA) perspective underpin the research. This paper summarises final outcomes and findings of the EuroSDR GeoBIM research project, which was set up to provide the required multi-national, usercentric collaborative framework, which had as its overall aim the development of best practice guidelines for GeoBIM, and due to its situation within EuroSDR has an NMCA focus. The paper updates information with regard to GeoBIM projects and maturity in the participant countries, and provides an overview of the two case studies developed.
\end{abstract}

\section{INTRODUCTION}

The use and value of location-based data within Geographical Information Systems (GIS) and from Earth Observation (e.g. satellite) sources has been long established for decision makers (e.g. O'Looney 2000, Jankowski 2001). For example, the United Kingdom Cabinet office recently compiled a report that lists ten high value themes (five pubic and five private sector, including sales and marketing, mobility, natural resources, security, emergency planning and response, citizen engagement) which have the potential for this data to unlock up to $£ 11$ billion per year of economic value along with social benefits (Cabinet Office 2018). Similarly, the commercial Earth Observation (EO) data market was estimated to have a value of $€ 1.5$ billion in 2015 with the opportunity to grow to $€ 2.6$ billion in 2025 (European Commission 2017 cited in Craglia and Pogorzelska 2020).

A more recent move within the construction sector from Computer Aided Design (CAD) to Building Information Modelling (BIM) has opened up an additional source of valuable locationbased data, with particular focus on the architecture, structural and engineering detail of both buildings and infrastructure projects, which is not traditionally included in information from GIS or EO. BIM is defined as A digital-based building design process that uses a single comprehensive system of computer models rather than separate sets of drawings (NBS 2017). While it is often thought of as intelligent 3D and 4D modelling approaches to construction in fact it has as its main aim collaboration (NBS 2017) between different stakeholders in construction, removing data silos. BIM activity can be broadly sub-divided into three categories (adapted from Jernigan 2008):

* Corresponding author
1. Building design - modelling the construction work at different levels of development (from concept to the detailed construction elements) and supporting a federated design involving different professionals (i.e. architects, structural engineers, installations designers and so on)

2. Project management - making efficient and effective use of this information to improve efficiency, reduce costs and waste during construction and operation

3. Information management - creation and long term curation of information relating to a built asset, at all phases of its lifecycle

This collaborative approach is expected to save a minimum of between 2 and $3 \%$ of the whole-life cost of projects (Price Waterhouse Coopers 2018), and people - the complex relationships between the social and technical resources that represent the complexity, collaboration and interrelationships of today's organisations and environments - are relevant to all aspects of BIM.

As with most if not all location data, while BIM can be used on its own, major benefits are to be derived from integration with other data sources. To date, integration has primarily been focused primarily on GIS, with the result known as GeoBIM. However, as anyone working with data is already aware, integrating disparate data sources is not necessarily an easy task. Two parallel issues arise - firstly, technical issues, in particular interoperability challenges, and secondly non-technical (e.g. organisational) challenges, including the clear identification of case studies which are needed to motivate and direct developers when addressing the technical challenges and to persuade senior management that 
investing time in this integration task is beneficial for their organisation.

While a number of research projects are addressing these challenges (e.g. the ISO/TC 59/ SC13 and ISO/TC211 working group on Interoperability between GIS and BIM, the Open Geospatial Consortium and buildingSMART International project on Built Environment Data Standards and their integration ${ }^{1}$, these are mainly standards focused. There are therefore synergies to be gained from a multi-national, coordinated approach, where participants can benefit from each-others' experience and where the needs of users and the NMCA perspective underpin the research.

This paper summarises final outcomes and findings of the EuroSDR GeoBIM research project, which was set up to provide the required multi-national, user-centric collaborative framework, which had as its overall aim the development of best practice guidelines for GeoBIM, and due to its situation within EuroSDR the project has an National Mapping and Cadastral Agency (NMCA) focus (see Section 2). Previous outputs of the project have been published in Noardo, Ellul, Harrie, Devys et al. (2019) and Noardo, Ellul, Harrie, Overland et al. (2019) and Ellul et al. (2018) and of the related benchmarking activity in Noardo, Arroyo Ohori et al. (2019) and Noardo, Biljecki et al. (2019) and Noardo, Arroyo Ohori et al. (2020). This paper first briefly summarises those outputs and then gives an integrated review of the project, updating information with regard to GeoBIM projects and maturity in the participant countries, and providing an overview of the two case studies developed.

\section{BACKGROUND -THE EUROSDR GEOBIM PROJECT}

EuroSDR is a not-for-profit organisation linking National Mapping and Cadastral Agencies (NMCAs) with Research Institutes and Universities in Europe for the purpose of applied research in spatial data provision, management and delivery 2 Within the organisation, work is divided into a total of six commissions (Data Acquisition, Modelling and Processing, Updating and Integration, Information Usage, Business Models and Operation, Knowledge Transfer) and activities include the coordination of multinational research activities, workshops, educational events and more.

The GeoBIM project was set up as a collaborative effort to bring together academics and practitioners from 13 countries. With an initial focus on understanding the broad picture (status, maturity levels) of GeoBIM across Europe, the project has subsequently updated this review on an annual basis and also developed two case studies that explore GeoBIM in more depth. A two-faceted approach was taken - firstly regular meetings of the entire team (at approximately 4-6 month intervals) allowed us to capture updates and progress with regard to GeoBIM activities within each of the partner countries. Secondly, two of the academic partners led more in depth case study development activities, with input provided during the meetings but also online through the project.

\subsection{Collaborators}

Collaborators included 13 NMCAs (Danish Geodata Agency, Denmark; Geodetic Institute of Slovenia; Glowny Urzad Geodezji i Kartografii, Poland; Lantmeteriet, Sweden; Institut Cartographic i Geologic de Catalunya; Institut national de

\footnotetext{
1 https://www . buildingsmart.org/buildingsmart-

international-bsi-and-open-geospatial-consortiumogc-release-bim-and-gis-integration-paper/ Accessed 5th May 2020

2 http://eurosdr.net/ Accessed 5th May 2020
}

l'information geographique et forestiere, France; Kadastre, Netherlands; Kartverket, Norway; National Land Survey of Finland; Ordnance Survey, Ireland; Ordnance Survey, UK; Survey and Mapping Authority, Republic of Slovenia; Swisstopo, Switzerland), one industrial partner (CSTB, France) and five university partners - TU Delft, Netherlands; University College London, UK; Lund University, Sweden; Dublin Institute of Technology, Ireland; University of Ljubljana, Slovenia.

\subsection{Similarities and Differences}

At the outset of the project, the team conducted a review (via a survey of collaborators and also of related literature) of key similarities and differences between geo and BIM, with a view that these would underpin any integration but also help to identify areas where research attention is required. The results are summarised in Table 1 and Table 2 (adapted from Ellul et al. 2018).

\begin{tabular}{|l|l|l|}
\hline Similarity & Geo & BIM \\
\hline $\begin{array}{l}\text { Information system combining at- } \\
\text { tributes and geometry }\end{array}$ & Yes & Yes \\
\hline Model the built environment in 3D & Yes & Yes \\
\hline Model indoor and outdoor features & Yes & Yes \\
\hline $\begin{array}{l}\text { Data can be managed in a database } \\
\text { management system }\end{array}$ & Yes & Yes \\
\hline $\begin{array}{l}\text { Spatial and non-spatial data editing } \\
\text { and management tools provided }\end{array}$ & Yes & Yes \\
\hline 2D and 3D visualization & Yes & Yes \\
\hline $\begin{array}{l}\text { Represent the world as is, but also } \\
\text { model historic and future repres- } \\
\text { entations }\end{array}$ & Yes & Yes \\
\hline Model at varying scales and detail & Yes & Yes \\
\hline
\end{tabular}

Table 1. Geo and BIM Similarities, adapted from Ellul et al. 2018

\subsection{Opportunities and Challenges for GeoBIM}

Given the user-centric focus of the EuroSDR GeoBIM project, an important element of previous work identified opportunities and challenges as perceived by the NMCAs - both technical and non-technical. As part of a survey, collaborators were asked to identify both, with particular focus on those relating to NMCAs.

As noted in Ellul et al. (2018) opportunities for GeoBIM include topographic mapping, cadastral systems, property valuation, highways management, statistics, building permits, urban planning, planning regulations, environmental planning, natural capital, infrastructure management, transport planning. Of these, building permits, urban planning, planning regulations relate to planning/permitting processes and NMCAs were particularly interested in the opportunity of enhancing their 3D city model offering with information from BIM, as well as options to provide their data as input into the planning process. A second grouping is given by infrastructure management and highways management to asset management. These groupings were selected as case studies for further development.

Challenges identified include (Ellul et al. 2018) a lack of knowledge and expertise on what GeoBIM is, BIM data coverage is lacking, the lack of articulation of role and services of an NMCA with regards to BIM and GeoBIM, different conceptual models, lack of skills within the construction field, lack of software, cost of model creation and lack of investment.

While the technical challenges are being addressed through research (within this group and elsewhere), ideas and approaches 


\begin{tabular}{|l|l|l|}
\hline Topic & Geo & BIM \\
\hline $\begin{array}{l}\text { Features } \\
\text { and } \\
\text { attributes }\end{array}$ & $\begin{array}{l}\text { Any spatial fea- } \\
\text { ture, any attrib- } \\
\text { utes but main fo- } \\
\text { cus on land and } \\
\text { cities }\end{array}$ & $\begin{array}{l}\text { Focus on features } \\
\text { of interest to con- } \\
\text { struction }\end{array}$ \\
\hline $\begin{array}{l}\text { Focus on data } \\
\text { flows within } \\
\text { Spatial Data } \\
\text { manage- } \\
\text { ment }\end{array}$ & $\begin{array}{l}\text { Infrastructure } \\
\text { (data quality, } \\
\text { validation, re- } \\
\text { sponsibilities), } \\
\text { databases, data } \\
\text { sharing }\end{array}$ & $\begin{array}{l}\text { ment for project } \\
\text { sites/ Focus on } \\
\text { data function- } \\
\text { alities in native } \\
\text { software, file- } \\
\text { based storage } \\
\text { with collabora- } \\
\text { tion tools }\end{array}$ \\
\hline $\begin{array}{l}\text { Key play- } \\
\text { ers }\end{array}$ & $\begin{array}{l}\text { Government } \\
\text { dominated }\end{array}$ & $\begin{array}{l}\text { Industry domin- } \\
\text { ated }\end{array}$ \\
\hline $\begin{array}{l}\text { Open } \\
\text { data }\end{array}$ & $\begin{array}{l}\text { Open } \\
\text { data/sharing } \\
\text { data is seen as } \\
\text { public good }\end{array}$ & $\begin{array}{l}\text { Sharing data } \\
\text { complex; bene- } \\
\text { fits for sharing } \\
\text { are not always } \\
\text { clear }\end{array}$ \\
\hline $\begin{array}{l}\text { Geometric } \\
\text { represent- } \\
\text { ation }\end{array}$ & $\begin{array}{l}\text { Geometry is } \\
\text { measured (B- } \\
\text { Rep) }\end{array}$ & $\begin{array}{l}\text { Geometry is de- } \\
\text { signed (paramet- } \\
\text { rized) }\end{array}$ \\
\hline $\begin{array}{l}\text { Geo- } \\
\text { referencing }\end{array}$ & $\begin{array}{l}\text { National, inter- } \\
\text { national }\end{array}$ & Local \\
\hline
\end{tabular}

Table 2. Geo and BIM Differences, adapted from Ellul et al. 2018

for addressing other challenges were proposed during a workshop held in Amsterdam in December 2019. Four key suggestions emerged from the workshop Noardo, Arroyo Ohori et al. 2020 - the need for interdisciplinary education relating to GeoBIM, the need for software and data to support GeoBIM activities, the need for more fully costed working case studies for GeoBIM and the need for a legal framework within which to request, for example, BIM for new buildings.

\section{METHODOLOGY - MATURITY LEVELS}

At the outset of the project in early 2018, each participant country was asked to complete a survey to give an overview of any GeoBIM related activity within their organisation (i.e. NMCA) or at national level. The results of this survey are published in Ellul et al. (2018), and also include an initial estimate of the level of GeoBIM maturity within each country. At each subsequent meeting, participants were asked to update the project on any new or ongoing initiatives. Additionally, to explore potential change over time, participants were once again asked to rate GeoBIM maturity within their country as input to this paper.

\section{METHODOLOGY - CASE STUDY DEVELOPMENT}

Initial project meetings and research Ellul et al. 2018 highlighted the need for more in depth case study development to help explore and convey the opportunities offered by GeoBIM integration to NMCAs and beyond. Based on their popularity in initial surveys, two studies were selected - planning/permits and asset management. It was also realised that due to the different levels of background knowledge and interest relating to these case studies within the team, different approaches were required.
The planning/permits study therefore developed as a multinational collaborative study which was able to align with related municipal and national initiatives in the Netherlands, Sweden and Norway, to develop a multi-national planning permit process workflow, identify stakeholders and, for each step in the workflow explore information required from BIM and from GIS, and the outcome of integration, which was then validated with stakeholders.

The asset management study identified at an early stage that while at an individual level (e.g. interviewees within asset management roles) interest in the potential of GeoBIM was high, this is not yet reflected through initiatives at organisational, municipal or national level. This is most likely due to the recent emergence of BIM - few built assets in operation today have access to BIM data and make use of this - or GeoBIM - for operational purposes. Thus, the case study was developed from a research perspective, with asset management researchers providing the expertise lacking in the EuroSDR group.

\section{RESULTS - MATURITY LEVELS}

Table 3 compares the level of maturity in participant countries from 2018 and 2020, with the maturity levels ranging form limited awareness through to considered leaders.

\begin{tabular}{|c|c|c|}
\hline $\begin{array}{l}\text { Country or } \\
\text { Region }\end{array}$ & 2018 & 2020 \\
\hline Catalunya & $\begin{array}{l}\text { A few small initi- } \\
\text { atives }\end{array}$ & $\begin{array}{l}\text { A few small initi- } \\
\text { atives }\end{array}$ \\
\hline Denmark & $\begin{array}{l}\text { A few small initi- } \\
\text { atives }\end{array}$ & $\begin{array}{l}\text { A few small initi- } \\
\text { atives }\end{array}$ \\
\hline Finland & $\begin{array}{l}\text { A few small initi- } \\
\text { atives }\end{array}$ & $\begin{array}{l}\text { A few small initi- } \\
\text { atives }\end{array}$ \\
\hline France & $\begin{array}{l}\text { A few small initi- } \\
\text { atives }\end{array}$ & $\begin{array}{l}\text { A few small initi- } \\
\text { atives }\end{array}$ \\
\hline Ireland & $\begin{array}{l}\text { Limited aware- } \\
\text { ness }\end{array}$ & $\begin{array}{l}\text { A few small initi- } \\
\text { atives }\end{array}$ \\
\hline Netherlands & $\begin{array}{l}\text { Ongoing activity } \\
\text { at regional and/or } \\
\text { national level }\end{array}$ & $\begin{array}{l}\text { Ongoing activity } \\
\text { at regional and/or } \\
\text { national level }\end{array}$ \\
\hline Norway & $\begin{array}{l}\text { Considered lead- } \\
\text { ers }\end{array}$ & $\begin{array}{l}\text { Considered lead- } \\
\text { ers }\end{array}$ \\
\hline Slovenia & $\begin{array}{l}\text { A few small initi- } \\
\text { atives }\end{array}$ & $\begin{array}{l}\text { A few small initi- } \\
\text { atives }\end{array}$ \\
\hline Poland & $\begin{array}{l}\text { Limited aware- } \\
\text { ness }\end{array}$ & $\begin{array}{ll}\text { Limited aware- } \\
\text { ness }\end{array}$ \\
\hline Sweden & $\begin{array}{l}\text { A few small initi- } \\
\text { atives }\end{array}$ & $\begin{array}{l}\text { Ongoing activity } \\
\text { at regional and/or } \\
\text { national level }\end{array}$ \\
\hline Switzerland & $\begin{array}{l}\text { Ongoing activity } \\
\text { at regional and/or } \\
\text { national level }\end{array}$ & $\begin{array}{l}\text { Ongoing activity } \\
\text { at regional and/or } \\
\text { national level }\end{array}$ \\
\hline $\begin{array}{l}\text { United } \\
\text { Kingdom }\end{array}$ & $\begin{array}{l}\text { A few small initi- } \\
\text { atives }\end{array}$ & $\begin{array}{l}\text { A few small initi- } \\
\text { atives }\end{array}$ \\
\hline
\end{tabular}

Table 3. GeoBIM Maturity Estimates

\subsection{Example Projects}

A number of participants of the EuroSDR project were able to add a little more detail to their current status report, giving - where applicable - descriptions of live projects in their regions or countries or adding context to the level of maturity. 
Catalunya report that current status is that they are still at early stages of BIM progress and are now starting to work with BIM more widely. Given this, GeoBIM is not really prominent yet, although there are efforts to promote this within the NMCA.

In Finland the Ministry of environment, NLS, BuildingSmartFinland and a number of municipalities are working on guidelines for harmonizing BIM data created for building permit process. Updating existing 3D city models with IFC2CityGML process is one of the drivers for the guidelines. Additionally, the Ministry of Environment has started a project to improve interoperability in the built environment sector. The project will implement a national digital registry and platform for land use and construction decision-making and processes. The platform aims to increase harmonization and interoperability for the stakeholders in the built environment sector by providing up-to-date and trustworthy data that has been modeled using common guidelines and standards 3

The team members from France report that they are not aware of much specific activity at the moment, but that there is activity to harmonize urban planning activities, currently focusing on 2D.

In the Netherlands, as noted in Section 6 activities relate in particular to GeoBIM in planning/permitting. Specifically, work relates to identifying the features that the BIM contains and how they can be altered in order for the exported BIM data to contain the information needed for the validation checks and their conversion to a GIS-effective Boundary-Representation format.

Norway has developed a standard to submit the BIM model into a planning/permit process (in collaboration with private companies who develop the software to process the data). However, they note that corresponding legal initiatives are still ongoing, and that BIM submission is still optional and under testing. As with other countries, municipalities are trying to harvest the submitted models to improve their maps and cadastral systems, and have developed an extraction tool focusing on the information they need, as well as on georeferencing. They also note that Architects are concerned about intellectual property rights embedded in the submitted designs. Within the NMCA, focus on BIM started in 2019 as part of a wider initiative relating to planning and the cadastre.

From the Slovenian side, there is an ongoing project on econstruction and e-planning, coordinated by the Ministry of Environment, who are also trying to automate the building permit process. The Ministry is collaborating with the University of Ljubljana to add GeoBIM into this project, and with this greater understanding of GeoBIM arising through a survey conducted by the University of Ljubljana.

Participants from Switzerland note that GeoBIM awareness is really gaining momentum, with city cantons interested in using BIM data and maintaining official buildings in a BIM, and at national level a strategy for GeoBIM for Swisstopo (the NMCA) being proposed, with the concept that the NMCA takes a lead role for national buildings/construction works on national and international standards. This is particularly the case as no private company that can guarantee a 100 year provider of BIM.

In the United Kingdom, initiatives relating to improving the planning permit process are being driven by the Connected Cities Catapult and the Royal Town Planning Institute, and their Future

\footnotetext{
3 https://www.ym.fi/fi-FI/Maankaytto_ja_rakentaminen/ Ohjelmat_ja_strategiat/Rakennetun_ympariston_ tietojarjestelma/Usein_kysyttya_rakennetun_ ympariston_tie(56664), in Finnish
}

of Planning report mentions the need for a standard schema for planning regulation $s^{4}$ but currently initiatives to streamlining the 2D process (detailed in Department for Communities and Local Government 2015) although a recent initiative by the Greater London Authority highlights investigation into the use of BIM for 3D Planning ${ }^{5}$ There are also efforts to develop a National Underground Asset Register to record any buried utilities in a single repository (700 stakeholders), but although implicit 3D and BIM have not yet been explicitly mentioned in this context. BIM Level 3 related work is ongoing within the Centre for Digital Built Britain (CDBB ${ }^{6}$, set up to develop the National Digital Twin) and the UK team members noted that focus is not on BIM but on the Digital Twin which is seen to extend the vision beyond just BIM (which is mostly perceived as constructioncentric). Publicly Available Specification (PAS) 1192-3, which specifies BIM-focused information management processes for the operational phase of assets, specifically mentions GIS as an example enterprise system that may link to the Asset Information Model but does not go into detail British Standard Institute 2014

\subsection{Participation in International Initiatives}

As part of their reporting at national level, France and Norway note participation in initiatives at international level - specifically, the International Standards Organisation (ISO) where there is an working group initiative on GIS and BIM interoperability between ISO/TC59/SC13 (ISO Technical Committee 59, Sub Committee 13, Organization and digitization of information about buildings and civil engineering works, including building information modelling (BIM) and ISO/TC211, Geographic information/Geomatics 7 The UK team also note that International standard ISO 19650 is closely aligned to the UK PAS 1192 serie 8 . with the standard focusing on managing information over the whole life cycle of a built asset using building information modelling (BIM)

\section{RESULTS - CASE STUDIES}

\subsection{GeoBIM and Planning/Permits}

6.1.1 Summary: The Planning/Permits Case Study (details in Noardo, Ellul, Harrie, Overland et al. 2019) was developed in collaboration with a number of municipalities, in particular the Municipality of Rotterdam in the Netherlands. The initial phase of the project involved developing a generic workflow for the issuing of a building permit that could be applied across multiple countries. This was followed by a more in-depth exploration of the workflow from the data and stakeholder/user perspectives, looking in particular at data exchange points from BIM to GIS and vice versa and at the information needs in each phase.

6.1.2 Benefits of a GeoBIM Approach: Results of the study show that using a GeoBIM approach for permits yields benefits throughout the planning lifecycle. Table 4 shows typical examples. In this table, for the sake of brevity, to link to the asset

\footnotetext{
4 https://www.rtpi.org.uk/press-releases/2019/ september/rtpi-and-connected-places-catapult-setout-vision-for-digital-future-of-planning/ Accessed 18 th May 2020

5 https://www.pbctoday.co.uk/news/bim-news/3dplanning-portal/75294/. Accessed 18th April 2020

6 https://www.cdbb.cam.ac.uk/ Accessed 18th May 2020

7 https://www.iso.org/standard/75105.html?browse=tc Accessed 18th May 2020

8 https://www . thenbs.com/knowledge/what-is-the-pas1192-framework. Accessed 2nd May 2020

9 https://www.bsigroup.com/en-GB/iso-19650-BIM/
} 
management case study and to simplify a complex workflow, examples are given in the context of small subset of the tasks relating to the Plan of Work stages defined by the Royal Institute of British Architects (RIBA) ${ }^{10}$ However, it is important to note that this is just a small extract and adaptation of the detail provided by this case study, which has identified a total of 14 planning stage/tasks where GeoBIM can be applied and analysed these in detail, as well as detailing stakeholder involvement and interested user groups. Preliminary work is reported in Noardo, Biljecki et al. (2019) and Noardo, Ellul, Harrie, Overland et al. (2019) with further details forthcoming.

\begin{tabular}{|l|l|l|}
\hline $\begin{array}{l}\text { RIBA } \\
\text { Stage }\end{array}$ & Sample Tasks & GeoBIM Application \\
\hline $\begin{array}{l}\text { Strategic } \\
\text { Defini- } \\
\text { tion }\end{array}$ & $\begin{array}{l}\text { Client require- } \\
\text { ments; Busi- } \\
\text { ness case }\end{array}$ & $\begin{array}{l}\text { What is permitted on this site } \\
\text { (GIS) and will it yield any } \\
\text { profit (BIM)? Should I pur- } \\
\text { chase this site? }\end{array}$ \\
\hline $\begin{array}{l}\text { Preparation } \\
\text { and } \\
\text { Briefing }\end{array}$ & $\begin{array}{l}\text { Sustainability } \\
\text { Studies }\end{array}$ & $\begin{array}{l}\text { Does this construction (BIM) } \\
\text { impact wildlife or cast shad- } \\
\text { ows (GIS)? }\end{array}$ \\
\hline $\begin{array}{l}\text { Concept } \\
\text { Design }\end{array}$ & $\begin{array}{l}\text { Agree design } \\
\text { with client }\end{array}$ & $\begin{array}{l}\text { Present design alternatives } \\
\text { (BIM) in the context of their } \\
\text { surroundings (GIS) }\end{array}$ \\
\hline $\begin{array}{l}\text { Spatial } \\
\text { Coordin- } \\
\text { ation }\end{array}$ & $\begin{array}{l}\text { Prepare and } \\
\text { submit plan- } \\
\text { ning applica- } \\
\text { tion, spatially } \\
\text { coordinated } \\
\text { design }\end{array}$ & $\begin{array}{l}\text { Contextual information - } \\
\text { what surrounds the building } \\
\text { - from GIS, along with en- } \\
\text { coded planning and building } \\
\text { regulations, with detailed } \\
\text { architecture and engineering } \\
\text { information from BIM, use of } \\
\text { location as an integrator }\end{array}$ \\
\hline
\end{tabular}

Table 4. Potential GeoBIM Applications for a subset of tasks from the RIBA Plan of Work Stages - Planning/Permits

\subsection{GeoBIM and Asset Management}

6.2.1 Summary: The Asset Management Case Study was developed in collaboration with colleagues in the Faculty of Architecture, Built Environment and Construction Engineering at the Politecnico di Milano, Italy. This was necessary due to the lack of asset management expertise within the EuroSDR group. The first stage of the study involved a literature review to identify existing studies on the topic, followed by the development of a practical, integrated, Asset Management database that linked data from BIM (specifically, a model of one of the campus buildings) and geospatial data of the surrounding neighbourhood. This integrated data (stored in PostGreSQL/PostGIS) was then enhanced with condition information about the assets - where a condition survey is a review of the condition of an asset and could include ratings ranging from as new, good serviceable condition to requires replacement within 5 years and in poor condition, overdue for replacement (Institute of Asset Management 2016). As an example of an application the three information sources - BIM, GIS and Condition information - can form the basis of 2D and 3D visualisations to show the current condition of each assets (with the potential to identify clusters leading to areas requiring priority intervention). This involved a three-way schema matching task (carried out manually), which helped to highlight the granularity of features of interest to AM/FM - for example, a condition survey could be conducted on a room as a whole, whereas in both

\footnotetext{
10 https://www . architecture.com/-/media/GatherContent/

Test-resources-page/Additional-Documents/

2020RIBAPlanofWorkoverviewpdf.pdf?la=en Accessed 10th May 2020
}

geospatial and BIM representations the room is built from multiple components.

6.2.2 Benefits of a GeoBIM Approach: While BIM provides a detailed $3 \mathrm{D}$ model of a built asset, such an asset is an integral part of its surrounding context - and it is rare that a facilities manager's responsibility does not extend beyond the door into a building. Additionally, while facilities management deals with the day to day operations of a structure (facilities management is defined as the organizational function which integrates people, place and process within the built environment with the purpose of improving the quality of life of people and the productivity of the core business, BS EN ISO 41011:2018), asset management looks at a higher, more value-focused, scale (asset management is defined as A coordinated activity of an organization to realise value from assets (ISO 55000), balancing costs, risks, opportunities to achieve organisation's objectives) multiple buildings, perhaps on multiple sites across the country. A GeoBIM approach can handle both levels of granularity, allowing the detailed condition surveys to be aggregated up into information useful at asset management level. This could have particular benefits for infrastructure management, where scales of operation are more traditionally geo (i.e. extended over a large area) than BIM (focused on one site) (see Table 2).

As with the planning/permits case it is also interesting to explore GeoBIM and asset management in the context of tasks extracted from the RIBA Plan of Work 11 Table 5 gives some examples.

\begin{tabular}{|l|l|l|}
\hline $\begin{array}{l}\text { RIBA } \\
\text { Stage }\end{array}$ & Sample Tasks & GeoBIM Application \\
\hline Handover & $\begin{array}{l}\text { Commissioning } \\
\text { and defect rec- } \\
\text { tification }\end{array}$ & $\begin{array}{l}\text { Carry out rapid condition sur- } \\
\text { veys and link the responses } \\
\text { to 3D GeoBIM geometry to } \\
\text { identify specific areas where } \\
\text { extensive rectification is re- } \\
\text { quired }\end{array}$ \\
\hline Use & $\begin{array}{l}\text { Facilities and } \\
\text { Asset Manage- } \\
\text { ment, verify } \\
\text { sustainability }\end{array}$ & $\begin{array}{l}\text { Pre-plan maintenance inter- } \\
\text { ventions virtually in the 3D } \\
\text { GeoBIM - e.g. working at } \\
\text { height - to ensure safety, ex- } \\
\text { ploit the location framework } \\
\text { to integrate temperature, air } \\
\text { quality and occupancy data to } \\
\text { validate building performance } \\
\text { predictions }\end{array}$ \\
\hline
\end{tabular}

Table 5. Potential GeoBIM Applications for a subset of tasks from the RIBA Plan of Work Stages - Asset Management

\section{DISCUSSION}

This paper gave a final review of the 2-year EuroSDR GeoBIM project, updating information with regard to GeoBIM projects and maturity in the participant countries, and providing a summary of the two case studies developed. Overall, it can be said that the project has been very successful, and the quantity and quality of outputs, workshops, meetings and related initiatives produced are a credit to the team involved, particularly given that the work was - to a great extent- voluntary. Indeed, a key strength of the project is the collaboration (and therefore support/involvement) of so many organisations in so many countries, which as made the project highly visible at national and international levels.

\footnotetext{
${ }^{11}$ The Plan of Work does not explore asset management in detail - e.g. there is no specific stage for modification of an existing asset
} 
Key outputs include a total of six project team meetings, one workshop held in collaboration with the sister project on GeoBIM benchmarking, in Amsterdam 2019), a GeoBIM in Asset Management workshop held in Milan in November 2019, a half day introductory session to GeoBIM (Paris, February 2020), numerous keynote and other talks (including in Singapore and Malaysia), and an online EuroSDR summer school on GeoBIM (23 participants, June 2020). Additional examples of impact include: within TU Dublin this project has been promoted across 100 parttime postgraduate students who work across the Irish AEC sector in consultants, contractors, subcontractors, government departments and agencies, and facilities management companies with backgrounds in architecture, architectural technology, construction management, engineering (civil, structural, building services), and surveying (geomatics, building and quantity); the project has been mentioned at the CitA BIM Gathering 2020 which is a 400-person conference run by the Construction IT Alliance and live-streamed as well as video recorded; the project has provided input into lecturing in many of the participant countries; presentation at the ISO TC 211 Seminar, in Slovenia; progress reports to the wider EuroSDR Board of Delegates.

Participants report that they have developed a far better understanding of the drivers for interest in GeoBIM within NMCAs, and the two case studies provide both theoretical and practical examples implementations of GeoBIM, helping to address the lack-of-awareness issue. This user-driven, user-focused project provides a balance to the more standards-driven collaborations (schema-focused) mentioned in Section 2 Regular meetings provided an avenue for those participants who rated their countries as being at few small initiatives to learn from others further down the GeoBIM path, and take this knowledge back to their home NMCAs to inform potential GeoBIM-focused strategic thinking. This, along with the various workshops, presentations, papers and other outputs from the project could in turn help to increase awareness of GeoBIM's potential and hence the national GeoBIM maturity level.

Both case studies involved collaboration outside the core geospatial discipline/expertise initially represented within the team, and as a result of this the planning/permits case study, in particular, did not only consider the integration of BIM into geospatial data but also the reverse - how the geospatial data could be utilised within a BIM environment and the asset management case study was able to articulate the potential of location as an integrator of the diverse information sources utilised within that discipline, with particular focus on aggregation/generalisation. These results highlight the need for an even more interdisciplinary approach to enable GeoBIM to reach its full potential benefit.

As with any study the results should be considered in context. Considering GeoBIM maturity levels first, Table 3 highlights that very little has changed in the time of activity of the project, with many countries still only reporting a few small initiatives, and those that started out with high levels of activity continuing in this vein. As the non-technical challenges identified in Section 2.3 highlight, even if some of the technical challenges could be addressed (see Noardo, Arroyo Ohori et al. 2020) this is not sufficient - and in fact it is hoped that the outcomes of this project will start to address the stated lack of understanding problem.

It can also be noted that many of the reported initiatives in Section 5 relate to planning. However there is a potential bias in this result due to the NMCA perspective taken by the project, which makes it possible that participants have greater awareness of public sector projects and are perhaps less aware of initiatives within the private sector. Additionally, the maturity level estimates are also a relatively subjective judgement by national representatives on the project, and may not represent the whole GeoBIM picture in a country (public or private sector), although they do give a good flavour of the focus of activity. A geospatial/NMCA focus is also a potential issue, as project team members may be less aware of initiatives driven from the BIM side.

Within the case studies, this focus on public sector examples is also reflected in the higher level of interest in in the planning/permits case study when compared to the asset management case study. Facilities and Asset Management are - in general - activities carried out by private entities, and given the relatively recent emergence of BIM, the potential to use this data, in combination with geo-data, for asset management has not yet been exploited significantly in practice. The relative simplicity of user requirements for Asset Management - a 3D location/simple 3D model with associated condition information - also contrast markedly with the complexity of the relevant standards (e.g ISO 19650, ISO 55000). This disparity between the ambitions of the standards and the needs, skills and current awareness of the users was further demonstrated during various meetings. While many of the interviewees in the Asset Management domain were aware of BIM some participants expressed scepticism that BIM - or even 3D modelling - was needed for asset management. There is thus a need for a more in depth end to end longitudinal case study linking standards, GeoBIM, Construction and Asset Management, to understand where GeoBIM can be of benefit and where existing methods are sufficient. It is also fair to say that the case for GeoBIM is perhaps less immediately obvious in facilities and asset management, where current research efforts focus on the use of BIM for facilities management (Ashton and Hou 2018, Alnaggar and Pitt 2019. Farghaly et al. 2017, Munir, Kiviniemi and Jones 2019). GeoBIM benefits are more apparent at asset portfolio level (multi-building, multi-site) and will further emerge within infrastructure facilities and asset management, although this is not yet mature as BIM standards do not yet cover infrastructure sufficiently, with standards only now emerging for bridges, waterways and tunnels, and the roads-related standards undergoing refinement ${ }^{12}$ Interestingly, this focus on infrastructure asset management is reflected in the initial opportunities identified within the project, where highways and infrastructure management were mentioned by participants (see Section 2.3.

\subsection{Further Work}

The EuroSDR project highlighted both the potential and complexity of GeoBIM integration, and the need to work with experts outside the geospatial discipline to achieve best results. Both case studies will, in fact, be further developed taking this into account.

Building on the initial collaboration within the EuroSDR project a wider network is being established around the topic of planning and permits ${ }^{13}$. This new initiative - the European Union Network for Digital Building Permits (EUnet4DBP) is intentionally multi-disciplinary and will build on the existing work, focusing on the development of digital building permit tools and methods, with the multi-national effort providing advantages in terms of improving interoperability, procedures and data optimization and standardization and creating/highlighting examples of high quality implementations.

From the asset management perspective, the concept of aggregating information from facility to asset to support multi-level de-

\footnotetext{
12 https://www.buildingsmart.org/standards/rooms/

infrastructure/ Accessed 20th May 2020

13 See the full list of entities and people at https://3d.bk.tudelft. nl/projects/eunet_bp/ Accessed 20th May 2020
} 
cision making, and its potential correspondence with map generalisation, will be further explored in collaboration with the team in Italy, who have developed a Facility Condition Index approach for decision support at building level (Moretti and Re Cecconi 2019) and are focusing on digital asset management (Re Cecconi et al. 2020).

Additionally, while planning/permits and asset management cover the majority of a built asset lifecycle, two stages of the RIBA Plan of Work have not been explored - technical design and manufacturing and construction. For the former, it may be interesting to explore whether the encoding of planning regulations proposed for the permit stage of development could be further adapted to building regulations (which focus on engineering detail), and for the latter there is an opportunity to explore supply chain logistics, identifying material quantities (BIM), best routes to site without disturbing neighbours (geo), on-site storage location (BIM)

\section{CONCLUSION}

The initial aim of the EuroSDR project was to develop best practice guidelines for GeoBIM, to provide input into NMCAs as to their potential role in relation to this integrated location dataset, and as a consequence help them to better understand their role in BIM, which is generating increasing quantities of locationenabled data due to various national mandates. The case studies achieved this in two senses - for the planning/permits case study, the detailed workflows developed (e.g. Noardo, Ellul, Harrie, Overland et al. 2019) give clear guidance as to where NMCA data and BIM data can be exchanged, and highlight the opportunity (but also the complexity) of using BIM as an information source for a 3D City Model. In contrast the asset management case study highlighted that there is at the moment a lack of maturity and understanding in asset management as to the potential of geospatial data, and that the role of an NMCA in this context perhaps initially relates to education, while waiting for BIM to mature sufficiently on the infrastructure side where GeoBIM benefits are clearer. Although not yet developed into formal guidelines further work is required before this could be achieved - the insights generated to date are already proving useful to the NMCA partners.

\section{ACKNOWLEDGEMENTS}

We would firstly like to thank EuroSDR, who funded elements of this work and also provided a framework within which to collaborate. In addition, a large part of this work was made possible thanks to the collaboration of the whole EuroSDR GeoBIM team (who provided input as in-kind contribution to the project, many of whom also hosted meetings). In particular, we are very grateful for participation in regular meetings and discussions as well as updates on national status and the opportunity to explore a number of national projects in depth.

In addition, we would like to acknowledge the contribution of $\mathrm{Dr}$ Nicola Moretti, Professor Fulvio Re Cecconi and Professor Mario Dejaco from the Politecnio Di Milano, who provided valuable input into the Asset Management case study.

The work of F. Noardo was also supported by Marie SkłodowskaCurie LEaDing feellow project, grant agreement No. 707404, Multisource Spatial data Integration for smart City Applications.

The authors would also like to thank Ordnance Survey GB (https://www.ordnancesurvey.co.uk) and 1Spatial (https://www.1spatial.com/) for sponsoring the publication of this paper.

\section{References}

Alnaggar, A., Pitt, M., 2019, Towards a conceptual framework to manage BIM/COBie asset data using a standard project management methodology. In: Journal of Facilities Management.

Ashton, H., Hou, L., 2018, Bridge Asset Management: A Digital Approach to Modelling Asset Information. In: ICCCBE 2018. International Society for Computing in Civil and Building Engineering.

British Standard Institute, 2014, PAS 1192-3: 2014-Specification for information management for the operational phase of assets using building information modelling.

Cabinet Office, 2018, An Initial Analysis of the Potential Geospatial Economic Opportunity. URL: https : / / assets . publishing . service . gov . uk / government / uploads / system / uploads / attachment _ data / file / 733864 / Initial_ Analysis _ of _ the _ Potential _ Geospatial _ Economic_Opportunity.pdf, visited on 17/05/2020,

Craglia, M., Pogorzelska, K., 2020, The Economic Value of Digital Earth. In: Manual of Digital Earth.

Department for Communities and Local Government, 2015, Plain English Guide to the Planning System.

Ellul, C., Stoter, J., Harrie, L., Shariat, M., Behan, A., Pla, M., 2018, Investigating the state of play of GeoBIM across Europe. In: International Archives of the Photogrammetry, Remote Sensing and Spatial Information Sciences-ISPRS Archives 42.4/W10, pp. 19-26.

Farghaly, K., Abanda, H., Vidalakis, C., Wood, G., 2017, BIM for Asset Management: A taxonomy of non-geometric BIM data for asset management. In: Conference EG-ICE 24th Workshop, Reino Unido.

Institute of Asset Management, 2016, Capital Investment Operation and Maintenance Decision-Making.

Jankowski, P., 2001, GIS for group decision making. CRC Press.

Jernigan, F. E., 2008, Big BIM, little bim: the practical approach to building information modeling: integrated practice done the right way! 4site Press.

Moretti, N., Re Cecconi, F., 2019, A Cross-Domain Decision Support System to Optimize Building Maintenance. In: Buildings 9.7, p. 161.

Munir, M., Kiviniemi, A., Jones, S. W., 2019, Business value of integrated BIM-based asset management. In: Engineering, Construction and Architectural Management.

NBS, 2017, The NBS guide to collaborative construction. URL: https : //www . thenbs . com/knowledge/the-nbs - guideto-collaborative-construction visited on 17/05/2020,

Noardo, F., Arroyo Ohori, K., Biljecki, F., Ellul, C., Harrie, L., Krijnen, T., Kokla, M., Stoter, J., 2020, The ISPRS-EuroSDR GeoBIM Benchmark 2019. In: International Annals of Photogrammetry, Remote Sensing and Spatial Information SciencesISPRS Archives.

Noardo, F., Ellul, C., Harrie, L., Devys, E., Arroyo Ohori, K., Olsson, P., Stoter, J., 2019, EuRoSDR GeoBIM project a study in Europe on how to use the potentials of BIM and GEO data in practice. In: International Archives of the Photogrammetry, Remote Sensing and Spatial Information Sciences-ISPRS Archives. 
4/W15. International Society for Photogrammetry and Remote Sensing, pp. 53-60.

Noardo, F., Arroyo Ohori, K., Biljecki, F., Krijnen, T., Ellul, C., Harrie, L., Stoter, J., 2019, GeoBIM benchmark 2019: design and initial results. In: International Archives of the Photogrammetry, Remote Sensing and Spatial Information Sciences-ISPRS Archives. 2/W13. ISPRS, pp. 1339-1346.

Noardo, F., Biljecki, F., Agugiaro, G., Arroyo Ohori, K., Ellul, C., Harrie, L., Stoter, J., 2019, GeoBIM benchmark 2019: Intermediate results. In: International Archives of the Photogrammetry, Remote Sensing and Spatial Information Sciences-ISPRS Archives. Vol. 42. International Society for Photogrammetry and Remote Sensing, pp. 47-52.

Noardo, F., Ellul, C., Harrie, L., Overland, I., Shariat, M., Arroyo Ohori, K., Stoter, J., 2019, Opportunities and challenges for GeoBIM in Europe developing a building permits use-case to raise awareness and examine technical interoperability challenges. In: Journal of Spatial Science, pp. 1-25.

O'Looney, J., 2000, Beyond maps: GIS and decision making in local government. ESRI, Inc.

Price Waterhouse Coopers, 2018, Quantifying the Benefits of BIM. URL: https : / / www . pwc . co . uk / industries / capital - projects - infrastructure / insights / quantifying - benefits - of - bim . html visited on $17 / 05 / 2020$,

Re Cecconi, F., Dejaco, M. C., Moretti, N., Mannino, A., Cadena, J. D. B., 2020, Digital Asset Management. In: Digital Transformation of the Design, Construction and Management Processes of the Built Environment. Springer, pp. 243-253. 